\title{
O CARNAVAL DE RUA DO RIO DE JANEIRO COMO UMA POSSIBILIDADE DE EXERCÍCIO DO DIREITO À CIDADE
}

\author{
THE STREET CARNIVAL OF RIO DE JANEIRO AS A POSSIBILITY OF \\ EXERCISING THE RIGHT TO THE CITY
}

Gustavo Silveira Siqueira*

\author{
Pedro Henrique Ramos Prado Vasques ${ }^{* *}$
}

\begin{abstract}
RESUMO: o presente artigo pretende discutir como o carnaval da cidade do Rio de Janeiro, mais especificamente, o carnaval dos blocos de rua, que ocupa grande parte da cidade, pode ser encarado como um exercício do direito à cidade. Ao mesmo tempo que o carnaval reúne milhares de pessoas nas ruas, traz consigo sujeira, prejudica o trânsito e espalha uma espécie de caos na cidade. Por outro lado, traz também benefícios, como uma fruição maior do comércio, a expansão da cultura popular, o lazer aos foliões. Dessa forma, discutir o carnaval carioca torna-se tema essencial para entender o direito ao acesso à cidade. $\mathrm{O}$ carnaval nas ruas do Rio de Janeiro é um carnaval eminentemente popular. A festa é gratuita; a prefeitura proíbe a criação de espaços reservados ou de camarotes nas ruas da cidade. Logo, em teoria, qualquer um pode fazer parte da multidão. Com blocos patrocinados e outros mantidos pelos próprios foliões, o carnaval altera a cidade. A rua deixa de ser apenas uma via - passa a ser ocupada por pessoas. O barulho dos veículos é substituído por músicas, tradicionais na maioria das vezes. Logo, mesmo trazendo o caos junto com a música e a cultura, a vivência do carnaval, como festa popular tradicional brasileira, torna-se claramente uma prática pública do direito à cidade, uma vez que o processo de gentrificação é momentaneamente neutralizado e a intervenção dos poderes públicos deve ser limitada apenas no sentido de facilitar e possibilitar uma convivência pacífica, jamais para proibir.
\end{abstract}

PALAVRAS-CHAVE: Carnaval de rua. Direito à cidade. Rio de Janeiro.

ABSTRACT: This article aims to discuss how the carnival of Rio de Janeiro, more specifically, the carnival of street blocks, which occupies much of the city, can be seen as an exercise of the right to the city. At the same time carnival brings together thousands of people in the streets, it also brings with it dirt, it affects traffic and spreads a kind of chaos in the city. On the other hand, it also brings benefits such as the increase of local trade, the expansion of popular culture, and leisure to the revelers. Thus, discussing the Rio carnival is an essential topic to understand the right of access to the city. The carnival in the streets of Rio de Janeiro is an eminently popular carnival. It is a free party; the municipality prohibits the creation of placeholders or cabins on city streets. Therefore, in theory, anyone can join the crowd. With sponsored blocks and other ones kept by revelers themselves, the carnival changes the city. The street is no longer just a pathway - it is now occupied by people. The noise of vehicles is

\footnotetext{
* Professor Adjunto IV e pesquisador do programa Prociência da Universidade do Estado do Rio de Janeiro. Pesquisador visitante da Fundação Biblioteca Nacional (PNAP-R), integrante do programa JCE da Faperj e membro do Instituto Brasileiro de História do Direito. Doutor em Direito pela Faculdade de Direito da Universidade Federal de Minas Gerais. E-mail: gsique@gmail.com

** Doutorando em Ciência Política na Universidade Estadual de Campinas (Unicamp). Mestre em Direito da Cidade na Universidade Estadual do Rio de Janeiro (Uerj).E-mail: pedrohvasques@gmail.com Revista da Faculdade de Direito - UFPR, Curitiba, vol. 60, n. 1, jan./abr. 2015, p. 137-161.
} 
replaced by music, traditional in most cases. So, even bringing chaos along with the music and culture, the experience of the carnival, as a traditional Brazilian popular party, clearly becomes a public practice of the right to the city, since the gentrification process is momentarily neutralized and the government power intervention has to be limited - never to prohibit, but only to facilitate and enable a peaceful coexistence.

KEYWORDS: Right to the city. Rio de Janeiro. Street carnival.

\section{INTRODUÇÃO}

A praça é do povo Como o céu é do condor

Castro Alves

Existem vários carnavais no Brasil: o carnaval das escolas de samba, o carnaval de rua, o carnaval dos trios elétricos. Talvez o carnaval seja um dos mais plurais e complexos movimentos culturais brasileiros. Discutir o carnaval é também discutir um pouco do Brasil.

O carnaval da cidade do Rio de Janeiro - mais especificamente, os blocos de rua, que ocupam consideráveis espaços na cidade - pode ser encarado como um exercício do direito à cidade. Ao mesmo tempo que reúne milhares de pessoas nas ruas da cidade, traz consigo sujeira, barulho e tumulto, espalhando uma espécie de caos urbano. Por outro lado, traz também benefícios - fruição maior do comércio, a expansão da cultura popular, o lazer aos brasileiros. Portanto, discutir o carnaval carioca torna-se tema essencial para entender o direito do acesso à cidade.

Desse modo, para melhor apresentar as questões aqui analisadas, dividimos o trabalho em três etapas. Na primeira, realiza-se, ainda que superficialmente, um exame sobre o planejamento urbano e o direito à cidade, pinçando desse arcabouço teórico elementos que nos ajudam a compreender a temática ora desenvolvida. No ponto seguinte, analisamos especificamente um elemento chave na percepção do carnaval no Rio de Janeiro, qual seja, a rua. Por fim, duas principais correntes de planejamento urbano são contrapostas e a questão do carnaval é também analisada comparativamente por meio destes dois olhares, destacandose, ainda, regulações, organizações e comportamentos verificados, tudo para contextualizar as referidas abordagens.

Por meio da observação dos eventos, da coleta de material bibliográfico e da documentação sobre o evento, apresentamos, sob a perspectiva própria dos autores, a compreensão acerca de como o carnaval de rua na cidade do Rio de Janeiro pode ser percebido a partir do planejamento urbano e, superficialmente, quais os detalhes a que se deve estar atento para minimizar as chances de que o evento seja apropriado integralmente pela lógica empreendedora capitalista. 


\section{O PLANEJAMENTO URBANO E O DIREITO À CIDADE}

No contexto de produção da cidade, o planejamento urbano surge como forma de intervenção do poder público no território. Essa condição própria surge no momento de florescimento do capitalismo industrial, em que os empregos no setor primário foram insuficientes para manter significativa parcela de população no campo. Esse aumento da concentração demográfica no meio urbano deu origem, portanto, a novas e complexas demandas de cunho social, como, por exemplo, saneamento, habitação e mobilidade.

Apesar de, inicialmente, ser identificado como política higienista, o planejamento urbano foi utilizado como instrumento para expansão e/ou criação de novas cidades. Como explica Santos (2006), ficaria evidente que, naquele momento, uma nova sociabilidade emergia, o que significa perceber novas formas de representação política do fenômeno urbano, principalmente considerando-se o caos das grandes cidades.

A partir do cenário que se desenvolveu após a consolidação do sistema econômico capitalista, as condições de reprodução social nas cidades fariam com que o conflito entre trabalho e capital se revestisse de uma dimensão territorializada, tornando o controle sobre o solo urbano e as políticas de infraestrutura urbana em elementos constitutivos do direito à cidade. Tal evidência coloca em xeque a subsequente abordagem tecnicista do planejamento urbano - que substitui o primeiro olhar higienista - e faz emergir a luta pela participação social nas políticas urbanas.

Nesse contexto, em que a necessidade de intervenção popular passa a ser percebida pelo poder público e reivindicada por seus citadinos, o conteúdo do direito à cidade passa a incluir acesso a direitos difusos e sociais. No exemplo brasileiro, esses direitos foram especialmente destacados a partir da Constituição Federal de 1988, como nos casos de meio ambiente, educação, saúde, assistência social e também moradia.

Diante dessas transformações, o planejamento urbano, mais uma vez, passa por um processo de reconstrução da sua finalidade e deixa de estar associado a uma visão que busca construir novas cidades ou projetos arquitetônicos idealizados, deslocados das dinâmicas social e econômica responsáveis pela emergência da questão urbana. Entretanto, o planejamento urbano também não pode prescindir de uma visão de futuro, se quer manter-se como instrumento orientador da expansão das cidades.

Nessa conjuntura, duas visões passam a disputar o sentido do planejamento urbano: a abordagem da urbanização social e do empreendedorismo urbano. A primeira está associada à implementação de uma gramática de direitos que implica não só políticas redistributivas, 
mas também ações de reconhecimento no ambiente urbano (e.g., identificação da favela como parte da cidade), materializada por meio do que chamamos de direito à cidade. A segunda vem predominando na administração das cidades - em particular, das metrópoles, como é o caso da cidade do Rio de Janeiro, que vem sofrendo intenso processo de transformação socioterritorial sustentada no projeto de sediar megaeventos até 2016 (e.g., Jornada Mundial da Juventude, Jogos Olímpicos, Copa do Mundo FIFA de Futebol, etc.).

Apesar do caráter eminentemente pejorativo que a perspectiva empreendedorista vem tomando - especialmente para os moradores mais vulneráveis, por ela atingidos, na cidade do Rio de Janeiro - cada uma das correntes destacadas ilumina partes distintas da complexidade associada às demandas urbanas. $\mathrm{O}$ urbanismo social remete para a necessidade de administrar a cidade de modo a torná-la acessível aos seus residentes, isto é, permitindo-lhes acesso à terra, à infraestrutura urbana e reconhecendo-os (também) como pertencentes àquele espaço urbano. Já o planejamento - empreendedorista - por projeto facilita a mobilização de recursos em escala suficiente para programar grandes blocos de investimentos em equipamentos urbanos de elevado custo.

Sob esse prisma, cabe ainda lembrar que o planejamento urbano também envolve dimensões distintas, como a regulação do uso do solo e o fomento ao desenvolvimento urbano.

A regulação urbanística é representada pela legislação que visa ao controle do uso e do processo de expansão urbana, em prol do cumprimento da função social da propriedade, atualmente revestida pelo interesse na promoção de um direito social e ambientalmente sustentável à cidade. Nesse sentido, trata-se de uma dimensão negativa do Direito, que tem o condão de impedir usos e apropriações do espaço urbano em favor da manutenção do interesse coletivo.

Por outro lado, o fomento ao desenvolvimento urbano está associado a prestações positivas do Estado, isto é, alocação de recursos para financiar a expansão da infraestrutura da cidade. Num contexto de crescimento extensivo da mancha urbana, extravasando para outros municípios e formando metrópoles muito mais complexas do que as cidades nucleares, tornase necessária a intervenção pública para viabilizar a produção de bens públicos, como são os casos da malha viária e da rede de saneamento. Tais investimentos pesados, por sua vez, tendem a produzir vetores de expansão urbana que suscitam respostas do mercado imobiliário. Essa relação entre implementação de serviços públicos e apropriação pelo mercado dos espaços urbanos e, consequentemente, crescimento da cidade, acaba por gerar mais demandas por infraestrutura urbanística, que, por sua vez, suscitam a necessidade de mais investimentos 
em equipamentos urbanos. $\mathrm{O}$ resultado tende a envolver mais engenharia financeira para administrar uma cidade cujos compromissos não são locais, mas sim parcelas significativas da economia do País.

Conforme evidenciam os Relatórios Anuais sobre a Situação da População Mundial produzidos pela ONU, é possível identificar, no âmbito das grandes cidades do mundo, um processo de concentração da população nessas metrópoles. Essas grandes cidades concentram parcela significativa do PIB nacional, além de boa parte da população de seus países. Nessas condições, tais cidades tornam-se centros econômicos e seus governantes assumem papel de grande relevância no cenário nacional (SANTOS, 2012a).

Fenômeno semelhante, ainda que em escala menor, ocorre no interior do território nacional, constituído pelos estados. Em cada uma dessas unidades da Federação há uma rede urbana constituída por cidades de diferentes pesos demográficos e econômicos, sendo que as mais importantes tendem a se tornar agentes que articulam o território estadual. Administrar essas cidades requer do poder público local a assunção de responsabilidades relativas às condições de vida de sua população, mas também o cuidado na adequada inserção das economias municipais nas redes de geração de produção, maximizando suas potencialidades. Não se trata de objetivos concorrentes; antes, devem ser complementares.

No Brasil, a Lei 10.257/01, conhecida como Estatuto da Cidade, que regulamenta os artigos 182 e 183 da Constituição Federal, define o plano diretor como o instrumento jurídico por meio do qual os governos municipais estabelecem seus objetivos de política urbana. Tais objetivos devem se submeter aos princípios dessa legislação, destacando-se a função social da propriedade e a função social da cidade, introduzindo aí a orientação para que os municípios se comprometam, entre outras coisas, com a regularização fundiária do espaço urbano.

O plano diretor, no entanto, não se resume a regular o uso do solo urbano, mas também inclui diretrizes para o desenvolvimento do território municipal como um todo. Essa inclusão da área rural no plano diretor acaba por expressar de forma mais direta o tema do desenvolvimento territorial, que pode ou não estar restrito às fronteiras municipais.

E aqui introduzimos a questão da forma jurídica de ordenamento do território nacional. Segundo o artigo 182 da Constituição de 1988, o município é o ente federativo responsável pela política urbana. A União manteve sua competência pelo estabelecimento de normas gerais de política urbana (e o fez pela edição do Estatuto da Cidade), ficando os estados com a responsabilidade pelas competências residuais (as que não são exclusivas da União ou dos municípios). 
Cabe lembrar que os avanços nos direitos sociais e difusos incluídos na Constituição ampliaram muito o entendimento do que seja um dos elementos constitutivos mais relevantes do planejamento urbano, isto é, o direito à moradia, que, por exemplo, passou a ser definido por "moradia adequada". Não se trata apenas da edificação, a unidade habitacional, mas sim de uma moradia regularizada em termos fundiários e de acesso às redes de infraestrutura urbana. Portanto, o compromisso das prefeituras com o planejamento urbano avançou para muito além da tradicional regulação urbanística, uma vez que passou a incluir investimento pesado em redes de infraestrutura cujo financiamento também está muito além da autonomia financeira municipal (SANTOS, 2012b).

Nessas condições, o enorme avanço normativo que o Movimento Nacional pela Reforma Urbana logrou instituir na Constituição de 1988 e no Estatuto da Cidade constitui apenas uma parte dos desafios da política urbana atual. Falta avançar na regulamentação municipal dessa legislação, bem como na articulação entre entes federativos para que cooperem em soluções de políticas públicas territoriais cujos impactos extravasem o município.

\section{A RUA E SUA APROPRIAÇÃO SOB A PERSPECTIVA DO DIREITO À CIDADE}

No curso da história do urbanismo, a rua foi em vários momentos negligenciada ou subaproveitada, chegando a ser definida por Le Corbusier (2000, p. 158) como "uma obraprima de engenharia civil e não mais um trabalho de cavouqueiros". É possível destacar momentos históricos de significativa relevância em que a rua foi utilizada também como instrumento estratégico para controle e dominação do espaço urbano, como, por exemplo, no caso das reformas urbanas de Paris conduzidas por Georges-Eugène Haussmann entre 1852 e 1870, que resultaram na criação de bulevares largos, extensos e lineares com o objetivo de extinguir as antigas vielas estreitas e cheias de curvas que impediram os exércitos de Napoleão de perseguir e dominar o território parisiense e facilitaram a criação de barricadas e de outras formas de resistência durante as revoluções populares de 1848 (HALL, 1995). Sob uma perspectiva similar, também calcada por um viés higienista, podem-se destacar as reformas conduzidas por Pereira Passos no centro da cidade do Rio de Janeiro. Tais modificações também visavam à extinção das vielas coloniais para a criação de amplas vias lineares que ligassem os dois portos do centro da cidade (ABREU, 1987).

A rua volta a ser e possuir uma posição de destaque no estudo do planejamento urbano a partir da década de 1960, com a produção do trabalho intitulado The death and life 
of great American cities (Traduzido em português como Morte e vida de grandes cidades), pela escritora e ativista política Jane Butzner Jacobs - esse trabalho ganhou repercussão e destaque em função de sua intensa luta contra as reformas urbanas pretendidas pelo então engenheiro-chefe da cidade de Nova Iorque, Robert Moses. Acredita-se que a maior colaboração de Jacobs, que lutava contra um processo de renovação urbana no bairro em que vivia, pode ser identificada na sua forma peculiar de análise do meio urbano. Sob uma perspectiva inovadora àquele momento, a autora buscava humanizar o processo de planejamento e implementação do território urbano. Em outras palavras, defendia que as próprias comunidades deveriam construir seu projeto social de ambiente urbano. Nesse sentido, Jacobs (2007) era uma oposição cristalina aos excessos planificadores que minguavam qualquer potencial de desenvolvimento das relações na construção do território.

Essa oposição de Jacobs pode ser identificada, por exemplo, na trivial percepção sobre a quantidade e funcionalidade das ruas e de seus respectivos cruzamentos. Enquanto Le Corbusier (2000, passim) entendia que "o número de ruas deve ser diminuído em dois terços", porque "o cruzamento de ruas é inimigo do trânsito", Jacobs (2007) defendia exatamente o oposto. Para a autora, a existência de quadras curtas e, portanto, de mais cruzamentos, seria essencial para impedir que as vizinhanças ficassem isoladas, separadas e desassistidas pela própria população. Para ela, essas ruas extensas produziriam um efeito autoisolador que inibiria inclusive a economia local. Isto é, trajetos longos e separados, segundo a autora, impediriam a formação de uma combinação de usos econômicos do espaço urbano. Assim, Jacobs identifica a rua como um espaço fundamental para a geração de diversidade. Para a autora, a multiplicidade de usos dessa parte do território urbano seria fundamental, entre outras coisas, para a integração de seus habitantes e a construção de uma rede de olhos citadinos responsáveis por colaborar com a segurança do bairro.

Apesar de Jacobs passar boa parte de seu livro defendendo o papel fundamental das ruas na construção de um espaço urbano plural capaz de atender às necessidades de seus habitantes, a autora não explora de forma exaustiva - e nem pretende - demais potenciais e possíveis usos das ruas em ambiente urbano, como no caso de manifestações culturais de larga dimensão. Todavia, o que é possível extrair do trabalho de Jacobs é que a rua detém características próprias de um potencial catalisador para produção (criação ou alteração) de ambiências urbanas. Isto é, a rua, por ser essencialmente pública, ampla, acessível e, em função da sua finalidade principal (servir de via para condução dos citadinos), é capaz de absorver a apropriação que lhe é dada em determinado momento e, em consequência, transformar-se. Daí a importância fundamental da rua na construção do ambiente urbano. 
Enquanto o ambiente privado permanecerá, em tese, restrito, absoluto, individualizado e imutável, o público, representado em sua excelência pela rua, detém uma capacidade mutacional agregadora capaz de produzir elementos plurais de mudança significativos na construção do território. Segundo Bauman (2009, p. 70), “os locais públicos são os pontos cruciais nos quais o futuro da vida urbana é decidido neste exato momento".

De forma exemplificativa, é possível ilustrar a afirmativa acima com algumas observações sobre o uso do referido espaço público: a rua, (i) em sua condição ordinária, é parte da infraestrutura urbana utilizada na condução dos habitantes que compartilham aquele território. Nessa condição, a rua é via, uma vez que é utilizada com essa finalidade específica por aqueles que buscam transitar no ambiente urbano; Todavia, (ii) ao ser apropriada em uma situação diversa da ordinária, sua condição de instrumento de infraestrutura urbana orientada para a mobilidade no âmbito da cidade fica em segundo plano. Nessa condição extraordinária, a rua pode ser - entre outras coisas - palco, pois pode ser utilizada como tal por aqueles que buscam, por exemplo, reivindicar direitos ou comemorar alguma festividade pública, como no carnaval de rua da cidade do Rio de Janeiro.

Assim, conforme apresentado, o espaço público - exemplificado pela rua no presente estudo - mostra-se como uma das possíveis ferramentas para a construção do espaço urbano diversificado e inclusivo e, consequentemente, para o exercício do direito à cidade. Essa perspectiva democrática pluralista acerca do urbanismo (isto é, que defende esta função para o espaço público) se contrapõe a uma visão privatista da cidade.

Desde a ascensão dos valores propagados no âmbito do renascentismo iluminista o ideário burguês de propriedade privada e, em especial, o direito à privacidade associado a esse espaço individual contribuíram para a produção do território e, mais especificamente, para o modo de apropriação do espaço urbano. A valorização do espaço privado íntimo em detrimento da praça pública são características marcantes associadas a esses valores.

Nesse sentido, a defesa da prevalência do ambiente privado em detrimento da diversidade possível de ser vivenciada no público deu origem, em diversas cidades no Ocidente - inclusive na cidade do Rio de Janeiro - à construção de amplos condomínios fechados de casas e apartamentos quase autossuficientes, equipados com uma extensa gama de serviços e infraestrutura para atender a (quase) todas as necessidades privadas de seus condôminos, expondo-os à cidade o mínimo possível. Esse negligenciamento do ambiente público - que, em última análise, exila o citadino em seu ambiente fechado - significa também afastar esse grupo de indivíduos, como afirma Bauman (2009), de um potencial contato com a diversidade, distanciando-o de seu respectivo valor criativo e de sua capacidade 
de tornar a vida mais intensa, que, por sua vez, tem como finalidade encorajar as diferenças à produção de um diálogo significativo. Assim, ao reduzir as possibilidades de formação de uma complexa rede social iniciada por meio do contato dos estranhos-anônimos que habitam o espaço público (BAUMAN, 2009), o reconhecimento da diversidade, pressuposto fundamental para o desenvolvimento de políticas públicas de reconhecimento (FRASER, 2007), deixa de ser socialmente construído, reduzindo a viabilidade de implementação das referidas políticas. Afinal, o reconhecimento para ser descoberto depende da interação com o outro. Essa interação ocorrerá, em grande medida, no espaço público - por exemplo, na rua. A fuga do ambiente privado burguês é, então, fundamental para tanto.

É esse contexto de tensão, de instabilidade associada ao desconhecido, que a rua traz consigo, e com o de solidez e segurança do espaço privado, que a apropriação do território é aqui percebida. Viver a rua, por consequência, significa irromper o urbano em busca dos seus atrativos associados. Todavia, a possibilidade de usufruir essa experiência está necessariamente associada à ausência de insegurança. Isso porque o medo - alimentado por um ambiente urbano inseguro - faz desaparecer das ruas, como afirma Bauman (2009, p. 68), "a espontaneidade, a flexibilidade, a capacidade de surpreender e a oferta de aventura". Segundo o referido autor $(2009$, p. 68), "a alternativa à segurança não é a beatitude da tranquilidade, mas a maldição do tédio". Desse modo, em um cenário como o urbano, cujo contato com o estrangeiro é constante, estar em contato com a diversidade passa a ser necessário não só para pensar políticas públicas de reconhecimento, mas também para mitigar a condição desse estranho-estrangeiro e, ao aproximá-lo, torná-lo um vizinho, afastando eventual sentimento de insegurança. É, portanto, por meio da criação de uma rede de sociabilidade própria, produzida em considerável medida pelo modo de apropriação do espaço urbano, que Jacobs (2007) entende ser possível criar territórios diversos e seguros, produzidos a partir dos interesses e necessidades do grupo social que o habita.

Toda a argumentação anteriormente desenvolvida tem como objetivo lastrear parte da análise sobre um determinado modo de apropriação da rua, qual seja, o carnaval de rua da cidade do Rio de Janeiro. Como se busca apresentar a seguir, a referida manifestação cultural possui características próprias fundamentais que podem servir, no caso de uma gestão conduzida a partir de um empreendedorismo urbano, para atender aos interesses do capital privado na construção de uma cidade espetáculo ${ }^{1}$, onde tudo está marcado pela circulação e

\footnotetext{
${ }^{1}$ Sobre o conceito de cidade espetáculo vale citar Sánchez (1999, p. 26): “A aspiração de colocar a cidade no novo mapa do mundo é perseguida por hábeis gestores do city marketing que fabricam também uma nova cidadania, um novo modo de ser e viver na cidade. É o que chamamos de cidade-espetáculo.” 
consumo de novos produtos urbanos (SÁNCHEZ, 1999). Ou, se apropriada pelo urbanismo social, como forma de construção de uma ambiência diversificada e inclusiva a partir de uma perspectiva participativa voltada para seus próprios habitantes.

\section{O CARNAVAL COMO FORMA DE APROPRIAÇÃO DA RUA E GARANTIA DO DIREITO À CIDADE}

O carnaval na cidade do Rio de Janeiro não é apenas aquele das Escolas de Samba, que desfilam em carros alegóricos, fantasias, adereços e sambas. Grande parte da festa do carnaval acontece na rua. São os tradicionais blocos de rua. No ano de 2013 - segundo informações da Riotur - desfilaram na cidade do Rio de Janeiro 492 blocos de rua, que reuniram, nos cinco dias oficiais de festa, cerca de cinco milhões de pessoas ${ }^{2}$.

Os blocos - alguns com quase 100 anos de história - são múltiplos e, muitas vezes, temáticos. São compostos por músicos e caminham pelas ruas da cidade tocando músicas e convidando as pessoas para participar da festa. Usualmente com autorização da prefeitura, os blocos ocupam as principais ruas e avenidas do Rio de Janeiro. A cidade, para ver os blocos passarem, para.

O ingresso do folião nos blocos não é controlado. Basta a pessoa seguir a caminhada. Diferentemente de outras cidades brasileiras - como Salvador-BA - onde existem cordas para a separação entre aqueles que pagam para seguir o bloco - como uma espécie de camarote na rua - e aqueles que não pagam, no carnaval do Rio de Janeiro não existem blocos com camarotes ou cordas que separam as pessoas. Todos os foliões são obrigados a compartilharem juntos - se desejarem participar - do Carnaval. No ano de 2013, quando a prática de criação de camarotes e cordas separando as pessoas voltou a ser cogitada, a prefeitura manifestou-se, por meio de decreto municipal, proibindo a criação de qualquer tipo de separação entre as pessoas. ${ }^{3}$

Vale a pena citar o Decreto municipal:

\footnotetext{
${ }^{2}$ Disponível em: <http://www.rio.rj.gov.br/web/guest/exibeconteudo?id=4142466>. Acesso em: 1 nov. 2014.

${ }^{3} \mathrm{O}$ secretário municipal de Turismo, Antonio Pedro Figueira de Mello, diz que não tolera a cordinha: "Ela não condiz com o carnaval carioca. Corda é só para as baterias. A rua é do povo, e não podemos permitir sua comercialização. O espaço onde os blocos desfilam é público. E é a prefeitura que legisla sobre esse espaço.” Já Rita Fernandes, presidente da Sebastiana - associação que representa 12 blocos - condenou o carnaval de lugares privilegiados: "O bloco que começa a lotear áreas vips com cordas e camisetas não é carnaval de rua. Pode ser em outro estado que não o nosso. (...) Isso já marca um caráter comercial. Não importa a linguagem musical, importa a intenção. Uma empresa que cria um bloco para vender abadás está fazendo uma apropriação. Isso é entretenimento, não carnaval". Disponível em: <http://oglobo.globo.com/rio/blocos-de-carnaval/rioturproibira-venda-de-abadas-area-vip-em-blocos-em-2014-7478120>. Acesso em: 1 nov. 2014.

Revista da Faculdade de Direito - UFPR, Curitiba, vol. 60, n. 1, jan./abr. 2015, p. 137-161.
} 
Decreto No 36760 de 05/02/2013

Publicado no DOM em 6 fev. 2013

Dispõe sobre a proibição da demarcação de áreas privadas nos blocos de carnaval na Cidade do Rio de Janeiro e dá outras providências.

O Prefeito da Cidade do Rio de Janeiro, no uso de suas atribuições legais, e

Considerando que o desfile das bandas, dos ensaios e dos blocos de Carnaval foi regulamentado pelo Decreto $\mathrm{n}^{\circ} 30.453$, de 09 de fevereiro de 2009;

Considerando que os blocos e bandas de rua, bem como os respectivos ensaios, são realizados em áreas e logradouros públicos, cabendo ao Poder Público Municipal regulamentar o uso do espaço público;

Considerando que o carnaval carioca se notabilizou pelos desfiles dos blocos de rua sem cordão de isolamento, livres e democráticos, típicos do jeito de ser e do modus vivendi da população da cidade;

Considerando a necessidade de controlar o fluxo de pessoas durante o desfile das bandas, dos ensaios e dos blocos de Carnaval na Cidade do Rio de Janeiro, de modo a se desenvolverem de forma ordeira e pacífica;

\section{Decreta:}

Art. $1^{\circ}$. Fica proibida, na Cidade do Rio de Janeiro, a delimitação de espaços, por meio de cordas e/ou seguranças ("áreas privadas"), pagos ou não, nos desfiles de blocos ou bandas de rua e nos ensaios carnavalescos de rua, no período de que trata o art. $1^{\circ}$ do Decreto $n^{\circ} 30.453 / 2009$.

Parágrafo único. Excepcionalmente, poderá ser delimitado espaço, por meio de cordas e/ou seguranças, para uso exclusivo dos integrantes da bateria e/ou da banda, bem como daqueles diretamente envolvidos na organização do desfile.

Art. $2^{\circ}$. Ficam automaticamente cassadas as autorizações já concedidas para os desfiles de blocos, bandas e ensaios carnavalescos que não respeitem o disposto neste Decreto.

$\S 2^{\circ}$ A RIOTUR, com o apoio da Guarda Municipal, adotará as medidas necessárias para coibir desfiles que contrariem o disposto neste Decreto.

Art. $3^{\circ}$. O não cumprimento do disposto no art. $1^{\circ}$ implicará no indeferimento do pedido de autorização para desfile nos períodos carnavalesco e pré-carnavalesco do ano subsequente, nos termos do art. 14 do Decreto $n^{\circ} 30.453 / 2009$.

Art. $4^{\circ}$. Este Decreto entra em vigor na data de sua publicação.

Rio de Janeiro, 5 de fevereiro de 2013; $448^{\circ}$ ano da fundação da Cidade.

EDUARDO PAES (grifo nosso)

O carnaval de rua carioca - materializado pelos diversos blocos organizados simultaneamente pela cidade - possui natureza democrática porque, além de ser experimentado na rua, que durante esse período transforma-se no palco público, é gratuito. Mesmo detendo precioso potencial inclusivo capaz de produzir diversidade, não é possível deixar de pensar a presente questão pelo viés dos processos de gentrificação ${ }^{4}$ somados aos resultados identificados na produção e apropriação do espaço urbano durante as festividades carnavalescas à luz da orientação conferida pelo poder público, especialmente no que tange ao modo como o evento é planejado e executado.

\footnotetext{
${ }^{4} \mathrm{O}$ conceito de gentrificação é compreendido a partir do trabalho desenvolvido por Smith (2006). O referido autor observa que áreas de baixo valor econômico na cidade e com alto potencial de obtenção de renda fundiária são potencialmente geradoras de gentrificação; em outras palavras, favorecem práticas especulativas por parte do capital imobiliário. Essa situação, por sua vez, tem como uma possível consequência o aumento do valor da terra, o que impossibilita os mais pobres de continuarem habitando as regiões renovadas por esse capital imobiliário especulativo. Trata-se, portanto, de uma estratégia que impulsiona a produção capitalista do espaço.

Revista da Faculdade de Direito - UFPR, Curitiba, vol. 60, n. 1, jan./abr. 2015, p. 137-161.
} 
Acreditamos ser possível relacionar os frequentadores dos blocos e os locais em que ocorrem os desfiles na cidade com o nível de interação entre classes sociais distintas na produção de diversidade. Isto é, apesar da condição democrática identificada na realização das respectivas festividades, haveria uma força capaz de potencializar a segregação geográfica produzida por efeitos gentrificadores que materializam as diferenças socioeconômicas na metrópole carioca. Dessa forma, acredita-se que, ao mesmo tempo que é possível identificar redutos em que há elevada interação das mais diversas classes sociais durante esse período, também é possível verificar que pequenas apropriações do espaço público por grupos menores podem transformar a rua-via não em um palco, mas sim na projeção do ambiente privado burguês.

Figura 1 - Desfile do Bloco Vira Lata, Leblon, Rio de Janeiro

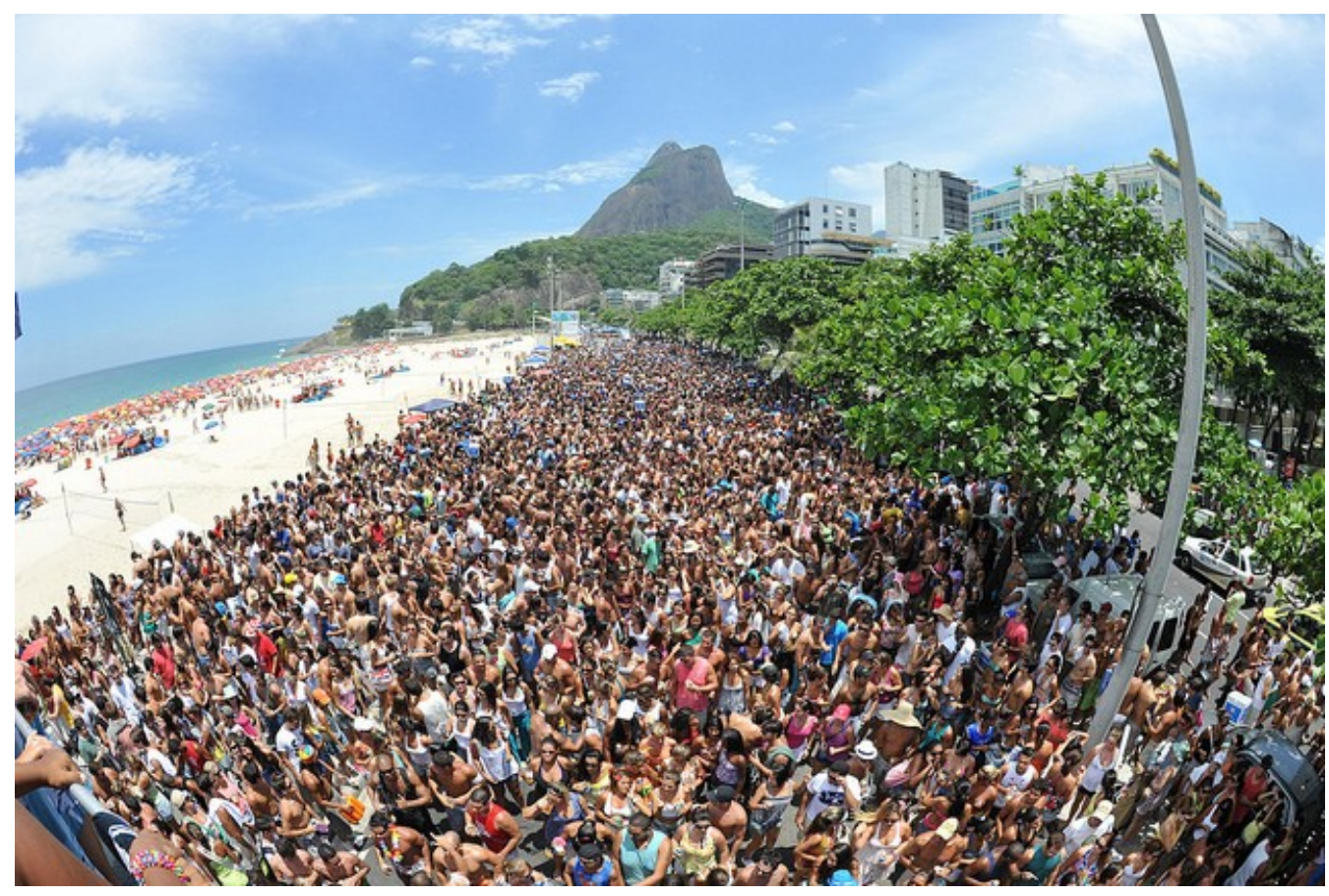

Fonte: Riotur ${ }^{5}$

O carnaval de rua possui significativo potencial de uso e domínio do urbano. Ainda que essa forma específica de apropriação da cidade ocorra por aproximadamente um mês durante o ano (considerando que os blocos iniciam antes e continuam ocorrendo depois do feriado de carnaval), a interação com o espaço público, o abandono do ambiente privado e o

\footnotetext{
${ }^{5}$ Disponível em: <https://www.flickr.com/photos/riotur/5442898456/>. Acesso em: 11 nov. 2014. Revista da Faculdade de Direito - UFPR, Curitiba, vol. 60, n. 1, jan./abr. 2015, p. 137-161.
} 
aproveitamento de todas as incertezas e expectativas que ele é capaz de oferecer é fundamental para construir em seus habitantes o sentimento de pertencimento à cidade.

É possível perceber que o carnaval carioca, que ocorre no espaço público por essência, que é a rua, não pode estabelecer distinções sociais ou privadas. A presidente da Sebastiana critica até mesmo a comercialização do carnaval. Se a prática do carnaval de rua é um patrimônio cultural, ele não pode ser apropriado ou privatizado.

A indústria cultural pode representar "a forma pela qual a produção artística e cultural se organiza dentro das relações capitalistas de produção" (MACHADO, 2009, p. 102). Neste sentido, a produção torna-se mercadoria e passa a valer de acordo com seu preço de mercado e não pelo "valor intrínseco que possa ter como obra científica, literária, filosofia etc." (MACHADO, 2009, p. 102).

Logo, o destinatário é simples consumidor da obra e não mais participante, criador: "trata-se de um bem para ser comprado, mas não para ser produzido pelo indivíduo; para ser usado momentaneamente, mas não para incorporar-se de modo definitivo à formação do sujeito" (MACHADO, 2009, p. 102).

De certa forma, o carnaval do Rio de Janeiro luta contra uma submissão total à indústria cultural. O carnaval, por mais que sofra influência de patrocinadores e de todo o sistema capitalista que gira em torno da festa, ainda pode ser medido pelo valor intrínseco. Ainda é possível perceber focos onde a industrial cultural não penetra ou focos onde a entrada da indústria cultural não impede que outras pessoas, que não querem ou não podem consumir os produtos vendidos, participem do carnaval, que ainda é aberto e gratuito. É claro que o consumo de bens gera uma diferenciação em todos os eventos, mas ele não leva a uma necessária exclusão.

Por outro lado, o carnaval ainda é produzido pelos indivíduos. É comum ver pessoas que fazem suas próprias fantasias, que criam novos blocos e que incorporam as festas ao dia a dia, sejam como construtores, como músicos ou meros participantes. $\mathrm{O}$ fato de ser uma festa gratuita e livre pode ser um fator de impedimento ao total domínio pela industrial cultural.

\subsection{O RIO NÃO É SALVADOR}

Foi comum ver no ano de 2010 grupos que desejavam criar camarotes ou espaços vips no carnaval da cidade. Um movimento chamado O Rio não é Salvador, que postava cartazes na cidade até 2013, fazia a defesa de um carnaval sem cordas, sem camarotes. 
O famoso carnaval de Salvador também ocorre nas ruas da cidade baiana; entretanto, com muitas divisões. Segundo a Professora Marília Veloso (2012), há três delas: os famosos que ficam nos camarotes, acima da rua, os brancos que ficam protegidos por cordas na rua e os negros que acompanham o desfile na parte livre. Veloso (2012, não paginado) chama o carnaval de Salvador de "apartheid" e percebe uma "ilha de brancos cercada por uma corda de negros". São os negros que seguram as cordas que fazem a separação, criando uma espécie de área vip próxima aos cantores.

A figura 2 abaixo possibilita perceber a separação dos grupos no carnaval de Salvador. Um grupo uniformizado (com os chamados abadás) dentro da corda, protegidos por outro grupo de funcionários do carnaval, também uniformizados. Ao lado, um camarote.

Figura 2 - Carnaval em Salvador

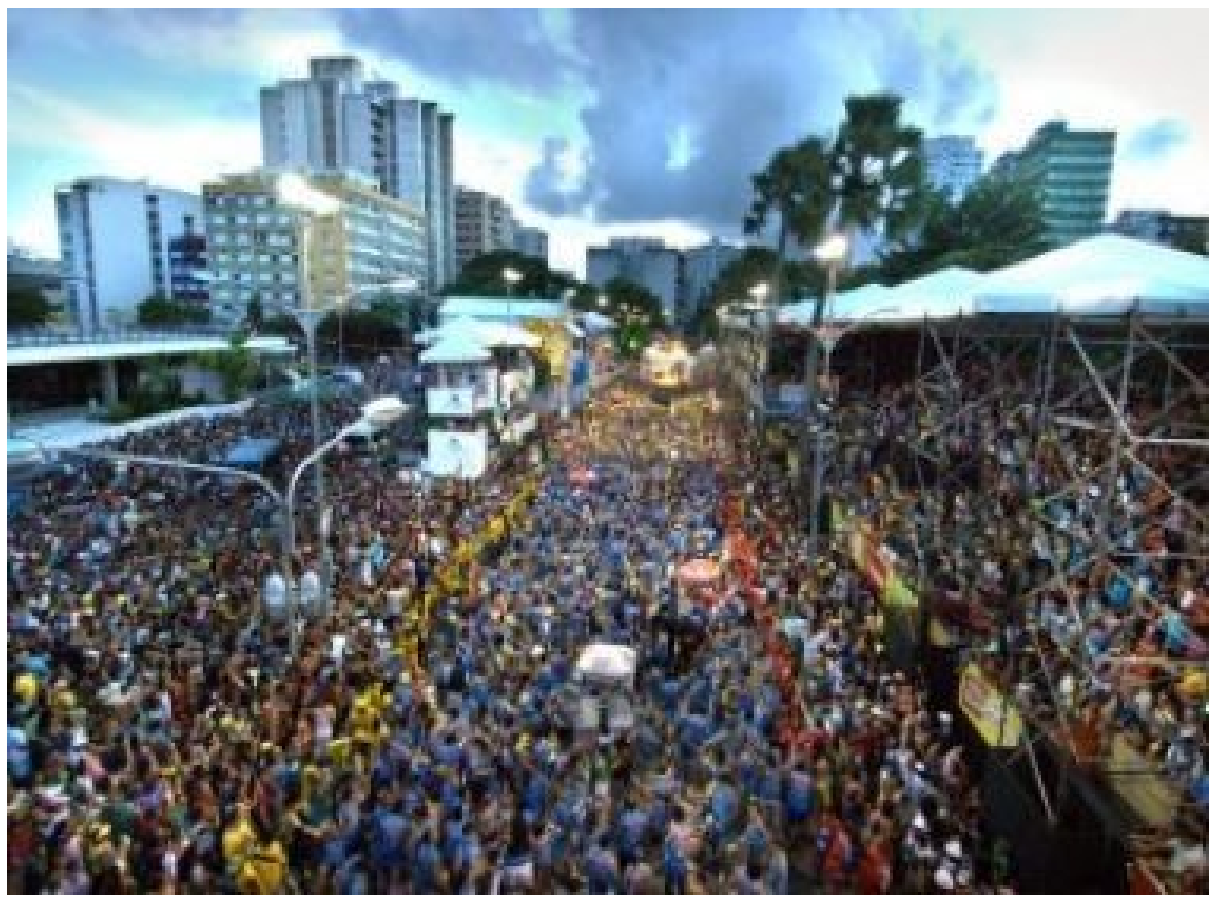

A separação dos foliões fica evidente a partir da cor de seus abadás: em azul os que pagaram para participar do bloco e em vermelho e amarelo os cordeiros, isto é, o cordão humano de seguranças impedindo a entrada de não pagantes no bloco.

Fonte: Bahia Notícias ${ }^{6}$

O que se pode dizer é que os mais diversos grupos do carnaval carioca querem evitar uma separação das pessoas, tal como a que acontece em Salvador. ${ }^{7}$

\footnotetext{
${ }^{6}$ Disponível em: <http://www.bahianoticias.com.br/cultura/noticia/13499-secult-divulga-artistas-selecionadospara-projeto-carnaval-pipoca-2013.html>. Acesso em: 11 nov. 2014.

Revista da Faculdade de Direito - UFPR, Curitiba, vol. 60, n. 1, jan./abr. 2015, p. 137-161.
} 
A tentativa é manter a cidade, que é um espaço de exclusão e diferenciações, pelo menos, neste período, um pouco mais plural, colorida e diversificada. A luta é para o carnaval do Rio não virar um carnaval de Salvador.

\subsection{O CARNAVAL E O CAOS URBANO}

Ocupando as ruas da cidade do Rio de Janeiro, o carnaval traz consigo problemas decorrentes de um grande agrupamento de pessoas. Já na sexta-feira (a festa oficialmente começa no sábado e termina na terça-feira) as principais ruas do centro são bloqueadas. Não oficialmente a festa começa, tradicionalmente, sexta-feira ao meio-dia.

Toneladas de lixo são deixadas por toda a cidade. O trânsito fica impraticável no centro e em alguns bairros. O número de notificações de furtos aumenta significativamente. Um pequeno caos instala-se nas ruas da cidade, onde os carros e seus barulhos são substituídos por pessoas e por músicas. As ruas são ocupadas por pessoas. Talvez elas retomem o lugar que lhes é de direito. Os carros são expulsos. O som é outro.

\footnotetext{
OCUPAÇÃO DO ESPAÇO PÚBLICO COMO EXERCÍCIO DA CIDADANIA

Hoje o espaço público é dos carros e a rua - que deveria ser democrática, lugar de convivência e aprendizado - um espaço hostil. Na contramão disto, tem uma época do ano, apenas um único momento, em que os carros dão lugar às pessoas e a hostilidade dá lugar à alegria. O CARNAVAL traz na ideia e na prática a ocupação do espaço público como forma de manifestação cultural, mas acima de tudo é um momento em que a cidade é das pessoas. ${ }^{8}$
}

Essa substituição tem os seus custos. Mas carrega consigo a alegria e a participação de milhões de pessoas. Um pouco de cultura é forjado no asfalto da cidade.

\footnotetext{
${ }^{7}$ Vale lembrar que a existência desse tipo de carnaval também é questionada na cidade de Salvador: "no dia 14 de janeiro, um protesto contra a privatização dos espaços públicos ocorreu em antecipação ao Carnaval de Salvador, uma das maiores festas de rua do mundo que irá começar no dia 18 de fevereiro. A manifestação foi claramente uma mensagem para o prefeito de Salvador (BA), João Henrique, e a empresa Premium retirarem um dos camarotes privados a ser utilizado durante a festa momesca. As estruturas de camarotes, de forma geral, ocupam uma grande área do espaço público na avenida principal do bairro de Ondina, onde o protesto ocorreu." Disponível em: <http://pt.globalvoicesonline.org/2012/01/28/brasil-movimento-reivindica-direito-ao-espacopublico-durante-carnaval-de-salvador/>. Acesso em: 15 nov. 2014.
}

Manifesto Carnavalista - Pelo Carnaval de Rua em São Paulo. Disponível em: $<$ http://www.kolombolo.org.br/blog/wp-content/uploads/2012/11/MANIFESTO-CARNAVALISTA.pdf $>$. Acesso em: 11 nov. 2014. 
Figura 3 - Alteração do trânsito no Centro do Rio de Janeiro no Carnaval

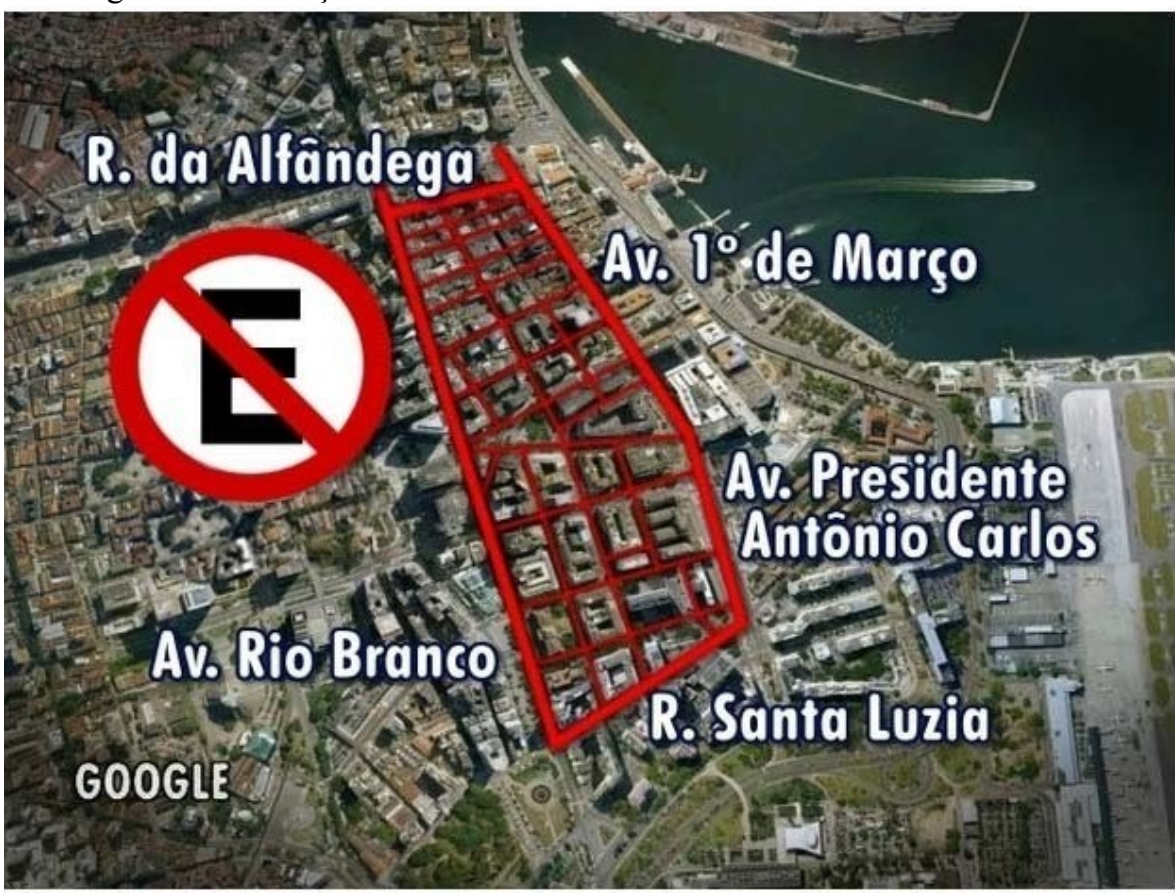

Fonte: RJTV, Globo 9

\subsection{O PALHAÇO E O BONDE}

O carnaval é uma festa plural. Seja pela multiplicidade de pessoas, seja pela diversidade das formas de manifestação. A convivência, muitas vezes rústica e apressada do dia a dia, por alguns momentos é substituída por modos de convivência diferentes.

Os policiais, presentes em alguns blocos para (teoricamente) protegerem as pessoas e o bom andamento do evento, podem, eventualmente, também fazer parte da festa. Se a violência policial, por exemplo, é um fenômeno que marca a vida nas cidades brasileiras, no carnaval, mesmo que brevemente, esta relação entre o policial que prende e o cidadão que é preso ou é vítima do bandido sofre alterações. O carnaval tem a força de mudar um pouco os papéis sociais e a sociedade no seu microcosmo.

\footnotetext{
${ }^{9}$ Disponível em: <http://g1.globo.com/rio-de-janeiro/carnaval/2013/noticia/2013/02/veja-o-esquema-de-transitono-rio-para-o-carnaval.html>. Acesso em: 11 nov. 2014. 
Figura 4 - Folião vestido de palhaço imitando guarda municipal durante Palhaceata no centro da cidade

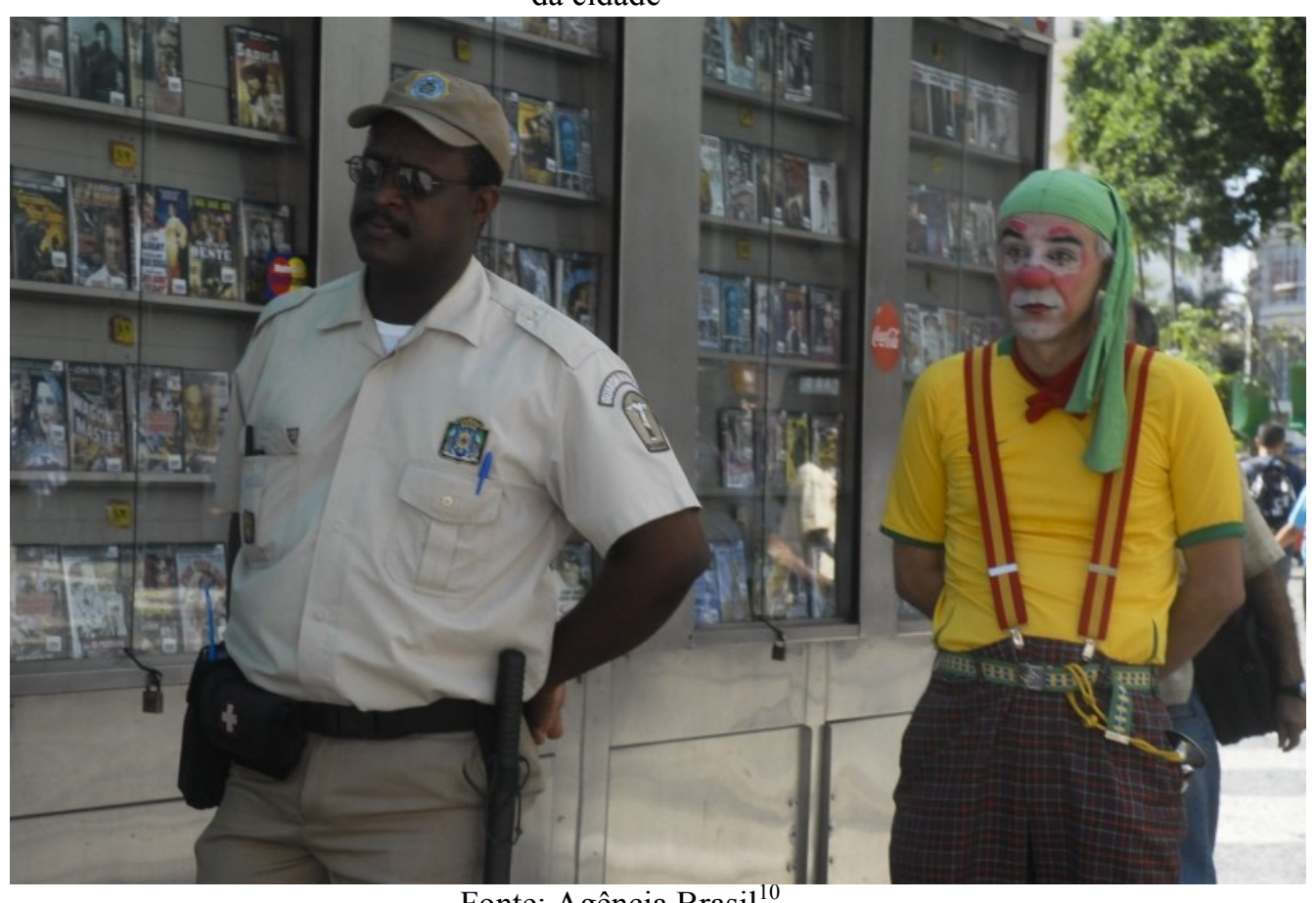

Fonte: Agência Brasil ${ }^{10}$

A figura 4 acima mostra a diversão de um palhaço com o guarda municipal. Também é comum ver - como em outras cidades brasileiras - homens vestidos de palhaços, durante o carnaval, parando o trânsito de carros para o bloco passar.

Não é possível esquecer que o furto de pequenos bens, como celulares e carteiras, multiplica-se no carnaval, como em qualquer grande festa popular. A polícia estaria ali para coibir tais práticas. Mas, no carnaval, outras possibilidades são possíveis, e o soldado também acaba virando um adereço.

Vale lembrar que a violência policial não desaparece de um dia para outro. A criminalidade aumenta. Mas tais relações, em uma pequena medida, são suavizadas pelas relações carnavalescas. É a abertura de um lapso, de uma nova possibilidade, que adorna os corações de homens e mulheres.

Mas o carnaval também é política. É muito comum ver protestos, faixas e cartazes pedindo serviços ou criticando a atuação da prefeitura ou do governo do Estado. O carnaval de 2013, por exemplo, foi marcado por vários protestos no bairro de Santa Teresa, que teve os bondes - um dos principais e mais tradicionais meios de transporte do bairro - desativados pela prefeitura. Em meio às músicas e aos palhaços dançando, era possível ver pessoas com

10 Disponível em: <http://memoria.ebc.com.br/agenciabrasil/galeria/2012-12-05/palhaceata-no-centro-do-rio>. Acesso em: 11 de nov. 2014. 
faixas e camisetas, lembrando a promessa, ainda não cumprida pela prefeitura, de reativar o serviço.

Já em 2014 foi possível verificar uma série de caricaturas do Prefeito Eduardo Paes e do Governador Sérgio Cabral, ambos vestidos de Hitler.

Figura 5 - Cantora Rita Lee pede volta do bonde em Santa Teresa

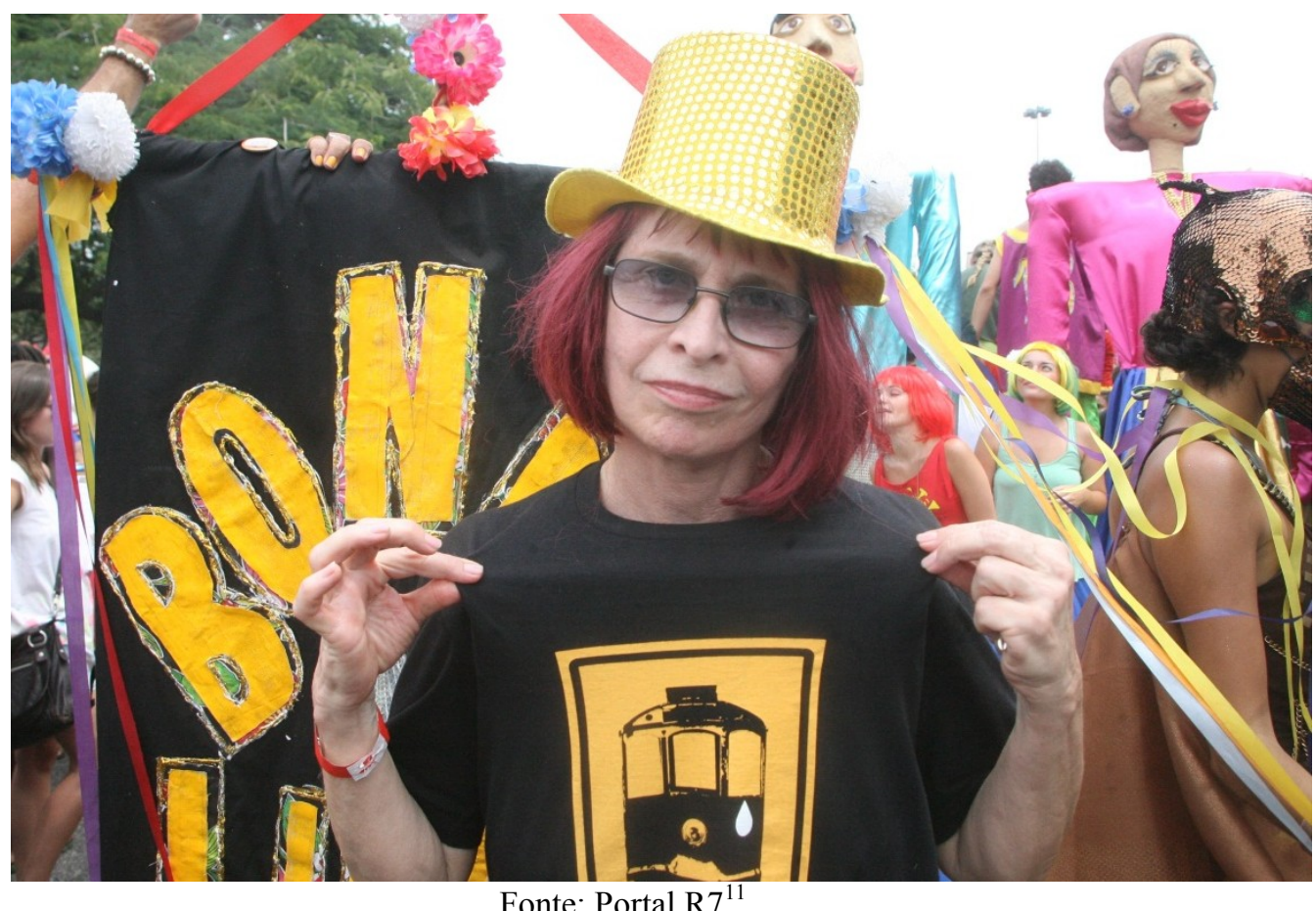

Personalidades brasileiras e estrangeiras são costumeiramente imitadas no carnaval. Palhaços convivem com pessoas fantasiadas de Homem-Aranha, Batman, Super-Homem, etc. Mas as pessoas também se fantasiam de presidentes, governadores, cobradores de ônibus, garis e músicos. Alguns com conotação política, para criticar, outros apenas para se divertir no meio do povo.

Uma das regras mais desoladoras para os foliões que se envolvem na temporária produção fantasiosa da cidade é a de que todo carnaval tem seu fim. Uma famosa música brasileira, de Vinícius de Moraes, explica como o mundo volta o normal depois do carnaval:

\footnotetext{
Acabou nosso carnaval/Ninguém ouve cantar canções Ninguém passa mais/Brincando feliz

E nos corações/Saudades e cinzas

Foi o que restou/Pelas ruas o que se vê

É uma gente que nem se vê/Que nem se sorri
}

\footnotetext{
${ }^{11}$ Disponível em: <http://noticias.r7.com/rio-de-janeiro/cidade-alerta-rj/videos/bloco-de-carnaval-pede-volta-dobonde-em-santa-teresa-rj-07072014>. Acesso em: 23 nov. 2014. 
Se beija e se abraça/E sai caminhando

Dançando e cantando/Cantigas de amor

A Marcha da quarta-feira de cinzas - no dia em que oficialmente se encerram as festividades - ilustra uma cidade que vê o carnaval acabar. E com ele vão-se também as músicas e as pessoas brincando na rua.

\subsection{A APROPRIAÇÃO DO CARNAVAL PELOS GESTORES PÚBLICOS}

Também se deve brevemente analisar, sob a ótica das correntes do planejamento urbano apresentadas anteriormente, tendo em vista a redefinição do papel do governo local após a Constituição Federal de 1988 (SANTOS, 2006), como o carnaval de rua carioca pode ser apropriado pelo gestor do território municipal e as consequências possivelmente verificáveis a partir desta ação. Em seguida, a partir das discussões existentes entre as duas correntes, problematiza-se o modelo de gestão que vem sendo adotado no âmbito da urbe carioca nos últimos governos e as consequências já verificáveis em função da adoção dessa orientação.

Por meio da perspectiva sustentada pelo empreendedorismo urbano, ou seja, a que defende a possibilidade de o poder público - com o objetivo de financiar obras de infraestrutura urbana - gerenciar a cidade a partir de potenciais projetos a serem executados em conjunto com a iniciativa privada (COMPANS, 2005), o carnaval (seja o desfile ou o carnaval de rua) é identificado como mais um dos grandes eventos que tem como função primeira preencher o cardápio de atividades que, por um lado, podem ser consumidas na cidade espetáculo e, por outro, podem servir estritamente para captação de recursos a serem investidos na própria cidade. Essa perspectiva empreendedora, cuja origem está associada ao término do Estado de bem-estar - quando a aplicação de medidas de austeridade econômica forçou os Estados a reduzirem investimentos em infraestrutura urbana - tem, ao menos em tese, o objetivo de servir de instrumento para financiamento de equipamentos urbanos de custo expressivamente elevado.

Todavia, a construção do espaço urbano com a finalidade de adequá-lo ao modelo de consumo internacionalmente desejado - para, então, captar recursos - pode produzir consequências das mais diversas e negativas no ambiente urbano, especialmente para grupos mais vulneráveis, ressignificando o território e conduzindo a um intenso processo de renovação urbana. Dentre os efeitos indesejados para os habitantes dessa cidade é possível destacar processos de gentrificação decorrentes (SMITH, 2006), entre outras coisas, da 
escolha das áreas, do modo de apropriação e da valorização dos espaços na cidade que, por sua vez, acabam ocorrendo para atender aos interesses do capital privado, sob a justificativa de que tais modificações são necessárias para financiar outros equipamentos urbanos.

Nesses casos, é possível observar efeito ainda mais perverso no que tange a esse modelo de produção do espaço urbano, qual seja, a transformação da cidade para morar em cidade para consumir, isto é, a cidade espetáculo. Uma utilização desmedida de estratégias empreendedoras no espaço urbano pode conduzir, assim, ao desvirtuamento do objetivo dessa proposta, produzindo um ambiente que, em verdade, atenderá majoritariamente aos interesses dos que lá chegam para consumir e/ou investir, deixando de lado as necessidades daqueles que habitam aquele território.

Por outro lado, sob a perspectiva do urbanismo social, pretende-se que o espaço urbano seja produzido por meio da mobilização produtiva do território, isto é, a interligação de aspectos sociais com a produção e geração de valor via combate à desigualdade e à exclusão por meio de dinâmicas de inserção socioeconômica (SILVEIRA, 2001). Portanto, segundo essa corrente, acredita-se que o carnaval estaria inserido nessa dinâmica de produção do urbano como forma de integração entre os diferentes grupos sociais com a finalidade de agregar os habitantes da urbe e produzir diversidade. Essa articulação caminharia ao lado de medidas inclusivas para geração de renda que, por sua vez, estariam dissociadas de um modelo de produção do espaço cuja orientação principal seria ditada pelo capital privado.

Ao passo que esse modelo de produção do meio urbano pretende-se mais inclusivo, pois prevê a construção do espaço por aqueles que o habitam, viabilizar a cidade, principalmente por meio de obras de infraestrutura urbana de grande magnitude, desconsiderando por completo a possibilidade de se valer de perspectivas de empreendedorismo urbano, pode se tornar um objetivo inalcançável. Dessa forma, acreditamos que a articulação de ambas as correntes, em medidas adequadas, pode resultar em avanços na produção de um espaço urbano diversificado e inclusivo.

No caso da cidade do Rio de Janeiro, desde 1993, com a elaboração do Plano Estratégico (COMPANS, 2005), a gestão pública municipal vem adotando um perfil de governança empreendedora. Atualmente, esse traço atinge um elevado grau de institucionalidade, com a realização de vultosos projetos urbanísticos a fim de atender à realização de megaeventos na cidade. Nos últimos anos foi possível verificar, ainda, verdadeira reformulação da estrutura municipal, redistribuição de competências, elaboração de novas normas e políticas públicas, estabelecimento de parcerias público-privadas e criação de novos instrumentos urbanísticos (VAINER, 2011). Nesse sentido, analisando, a partir do 
olhar sugerido por Harvey $(2006 ; 2011)$, essas alterações conduzidas na geografia e na própria institucionalidade pelo executivo municipal, pode-se extrair que o que vem sendo estimulado atualmente na cidade é o desenvolvimento da capacidade localizadora de valorização do capital, como fazem o turismo, o espetáculo e os megaeventos.

Para a cidade espetáculo, é indesejável que se dê visibilidade às mazelas sociais e à desordem urbana: uma nova estética se impõe, e requer a expulsão da população de baixa renda para as regiões periféricas da cidade, pouco atrativas ao capital imobiliário. Desse modo, portanto, ficam evidentes os riscos de se incorporar, no planejamento urbano, conceitos reificados de outras cidades mundiais - como no presente caso, em que a cidade de Barcelona foi o modelo a ser estudado para fins de conceber os projetos urbanísticos empreendedores para a cidade do Rio de Janeiro - que tendem a conduzir o empreendedorismo urbano para um processo de urbanismo negocial, com objetivos mais econômicos do que urbanísticos (MARICATO, 1997).

Especificamente sobre o carnaval de rua carioca, é possível verificar que, atualmente, este também foi apropriado pela referida perspectiva empreendedora. Apesar de o Executivo municipal haver sinalizado que impediria qualquer forma de privatização dos blocos ${ }^{12}$ vedando a instituição de cobranças - o carnaval de rua do Rio de Janeiro é tido como mais um dos grandes projetos conduzidos pelos gestores municipais. Ocorre que, a despeito de as festividades carregarem a dimensão empreendedora, a manutenção de suas características essenciais - isto é, serem conduzidas na rua e a gratuidade dos eventos - não inibe significativamente o potencial inclusivo do carnaval de rua como exercício do direito à cidade.

\section{CONSIDERAÇÕES FINAIS}

Apesar de o carnaval de rua gratuito não ser uma característica exclusiva da cidade do Rio de Janeiro, essa condição é fundamental para perceber o referido fenômeno como capaz de propiciar àqueles que o vivenciam uma livre experiência sobre o urbano. Nesse sentido, esse carnaval popular proporciona, ainda que por curto espaço de tempo, uma ressignificação de determinados espaços da cidade - no caso estudado, a rua - que, durante as festividades, deixam de ser percebidos como exclusivamente um meio de passagem, para se constituírem como destino. Essa transformação, ainda que temporária, faculta aos seus

\footnotetext{
${ }^{12}$ Disponível em: <http://g1.globo.com/pop-arte/noticia/2013/02/grupo-de-blocos-se-rebela-contra-privatizacaodo-carnaval-de-rua-carioca.html>. Acesso em: 13 maio 2013. 
habitantes a possibilidade de estarem no centro de um turbilhão de experiências que, em última análise, concentra a capacidade de surpreender e a oferta de aventura no espaço urbano.

A percepção sobre a utilização da rua como finalidade (palco), a interação com esse espaço público e o abandono do ambiente privado são elementos valiosos para construir nos habitantes um sentimento de pertencimento ao território. Dessa forma, o carnaval de rua pode ser percebido como um exercício do direito à cidade e também como um exercício de manifestação política. Portanto, a manutenção dessas características essenciais do carnaval de rua demanda a necessidade de se estar atento, a fim de se evitar que o empreendedorismo urbano irrompa, de forma desregulada, em direção à espetacularização do carnaval de rua, descaracterizando-o quanto ao seu apelo popular. Assim, entre outras coisas, é possível perceber que a manutenção da atual característica, de amplo e irrestrito acesso às festividades de rua, é essencial para que possamos percebê-las como instrumentos de exercício de acesso à cidade.

\section{REFERÊNCIAS}

ABREU, Maurício. A evolução urbana do Rio de Janeiro. Rio de Janeiro: IplanRio; Zahar, 1987.

AGÊNCIA BRASIL. Palhaceata no centro do Rio. 5 dez. 2012, 20:40. Disponível em: $<$ http://memoria.ebc.com.br/agenciabrasil/galeria/2012-12-05/palhaceata-no-centro-do-rio>. Acesso em: 11 de nov. 2014.

ALVES, Castro. Poesias Coligidas. In: Castro Alves - Literatura Comentada. São Paulo: Abril Educação, 1980.

BAUMAN, Zygmunt. Confiança e medo na cidade. Rio de Janeiro: Zahar, 2009.

BN CULTURA. Secult divulga artistas selecionados para Projeto Carnaval Pipoca 2013. Terça, 4 dez. 2012 - 14:06. Disponível em: $<$ http://www.bahianoticias.com.br/cultura/noticia/13499-secult-divulga-artistas-selecionadospara-projeto-carnaval-pipoca-2013.html>. Acesso em: 11 nov. 2014.

COMPANS, Rose. Empreendedorismo urbano: entre o discurso e a prática. São Paulo: Editora Unesp, 2005.

FLICKR (SECRETARIA DE TURISMO DA CIDADE DO RIO DE JANEIRO). Bloco Vira Lata desfile na orla do Leblon, domingo 13 de fevereiro de 2011. Cerca de 15 mil pessoas dançaram ao som do trio elétrico. Foto: Paulo Mumiia | Riotur. Disponível em: $<$ https://www.flickr.com/photos/riotur/5442898456/>. Acesso em: 11 nov. 2014. 
FRASER, Nancy. Reconhecimento sem ética? In: SOUZA, Jessé; MATTOS, Patrícia (Org.) Teoria crítica no século XXI. São Paulo: Annablume, 2007. p. 113-140.

GLOBALVOICES. Brasil: Movimento Reivindica Direito ao Espaço Público durante Carnaval de Salvador. Tradução publicada em 28 jan. 2012, 22:43 GMT. Disponível em: $<$ http://pt.globalvoicesonline.org/2012/01/28/brasil-movimento-reivindica-direito-ao-espacopublico-durante-carnaval-de-salvador/>. Acesso em: 15 nov. 2014.

GLOBO.COM. Grupo de blocos se rebela contra 'privatização' do Carnaval de rua carioca. 08 fev. 2013 06h03 - Atualizado em 08 fev. 2013 06h03. Disponível em: $<$ http://g1.globo.com/pop-arte/noticia/2013/02/grupo-de-blocos-se-rebela-contra-privatizacaodo-carnaval-de-rua-carioca.html>. Acesso em: 13 maio 2013.

.Veja o esquema de trânsito no Rio para o carnaval. 10 fev. 2013, 14h25 - Atualizado $\overline{\mathrm{em}} 10$ fev. 2013, 15h29. Disponível em: <http://g1.globo.com/rio-dejaneiro/carnaval/2013/noticia/2013/02/veja-o-esquema-de-transito-no-rio-para-ocarnaval.html>. Acesso em: 11 nov. 2014.

GRÊMIO RECREATIVO DE RESISTÊNCIA CULTURAL KOLOMBOLO DIÁ PIRATININGA. Manifesto Carnavalista pelo Carnaval de Rua de São Paulo. Disponível em: $<$ http://www.kolombolo.org.br/blog/wp-content/uploads/2012/11/MANIFESTO-

CARNAVALISTA.pdf>. Acesso em: 11 nov. 2014.

HALL, Peter. Cidades do amanhã. São Paulo: Perspectiva, 2007.

HARVEY, David. A produção capitalista do espaço. São Paulo: Annablume, 2006. . O enigma do capital e as crises do capitalismo. São Paulo: Boitempo, 2011.

JACOBS, Jane. Morte e vida de grandes cidades. São Paulo: Martins Fontes, 2007.

LE CORBUSIER. Urbanismo. São Paulo: Martins Fontes, 2000.

MACHADO, Antônio Alberto. Ensino jurídico e mudança social. São Paulo: Expressão Popular, 2009, p. 102.

MARICATO, Ermínia. Brasil 2000: qual planejamento urbano? Cadernos IPPUR. Ano XI, n. 1 e 2. Rio de Janeiro: IPPUR, jan.-dez. 1997.

O GLOBO. Riotur proibirá venda de abadás e área vip em blocos em 2014. 3 fev. 2013 7:00 / Atualizado 3 fev. 2013 11:16 Disponível em: <http://oglobo.globo.com/rio/blocos-decarnaval/riotur-proibira-venda-de-abadas-area-vip-em-blocos-em-2014-7478120>. Acesso em: 1 nov. 2014.

RIO DE JANEIRO (cidade). Decreto 36.760. Dispõe sobre a proibição da demarcação de áreas privadas nos blocos de carnaval na Cidade do Rio de Janeiro e dá outras providências. Diário oficial do município, Rio de Janeiro, RJ, 6 fev. 2013. Disponível em: < http://www.legisweb.com.br/legislacao/?id=251074>. Acesso em: 1 nov. 2014. 
. Prefeitura municipal. Riotur divulga lista dos blocos do carnaval de rua 2013. 10 jan. 2013. Disponível em: <http://www.rio.rj.gov.br/web/guest/exibeconteudo?id=4142466>. Acesso em: 1 nov. 2014.

R7 NOTÍCIAS. Bloco de Carnaval pede volta do bonde em Santa Teresa (RJ). 8 fev. 2013 às 20h54 (Atualizado em 7 jul. 2014 às 16h08). Disponível em: <http://noticias.r7.com/rio-dejaneiro/cidade-alerta-rj/videos/bloco-de-carnaval-pede-volta-do-bonde-em-santa-teresa-rj07072014>. Acesso em: 23 nov. 2014.

SÁNCHEZ, Fernanda. Arquitetura e urbanismo: espaços de representação na cidade contemporânea

. In: Revista Veredas, Rio de Janeiro, Centro Cultural Banco do Brasil, v. 4, n. 41, maio de 1999, p. 26-9.

SANTOS, Angela Moulin S. Penalva. Finanças Públicas: uma análise da autonomia financeira dos municípios brasileiros na primeira década do século XXI. Revista do Tribunal de Contas do Estado do Rio de Janeiro. Vol. 7, n. 1, Rio de Janeiro: O Tribunal, jan./jun. 2012.

. Planejamento urbano: para quê e para quem? Revista de Direito da Cidade. N. 1, vol. 1, Rio de Janeiro: UERJ, 2006.

SILVEIRA, Caio Márcio. Miradas, métodos, redes - o desenvolvimento local em curso. Disponível em: $<$ http://www.iets.inf.br/biblioteca/Miradas_metodos_redes_o_desenvolvimento_local_em_cur so.pdf>. Acesso em: 13 maio 2013.

SMITH, N. A gentrificação generalizada: de uma anomalia local à "regeneração" urbana como estratégia urbana global. In: BIDOU-ZACHARIASEN, C. (Org.). De volta à cidade. São Paulo: Annablume, 2006.

VAINER, Carlos. Cidade de exceção: reflexões a partir do Rio de Janeiro. In: XIV Encontro Nacional da Anpur, 2011. Disponível em: <http://www.opp.ufc.br/urbano04.pdf $>$. Acesso em: 12 maio 2013.

VELOSO, Marília Lomanto Veloso. Carnaval de Salvador: "apartheid" e seletividade em uma ilha de brancos cercada por uma corda de negros. Disponível em: $<$ http://racismoambiental.net.br/2012/02/carnaval-de-salvador-

$\% \mathrm{E} 2 \% 80 \% 9$ Capartheid $\% \mathrm{E} 2 \% 80 \% 9 \mathrm{D}$-e-seletividade-em-uma-ilha-de-brancos-cercada-poruma-corda-de-negros/>. Acesso em: 21 maio 2013.

\title{
THE STREET CARNIVAL OF RIO DE JANEIRO AS A POSSIBILITY OF EXERCISING THE RIGHT TO THE CITY
}

\begin{abstract}
This article aims to discuss how the carnival of Rio de Janeiro, more specifically, the carnival of street blocks, which occupies much of the city, can be seen as an exercise of the right to the city. At the same time carnival brings together thousands of people in the streets, it also brings with it dirt, it affects traffic and spreads a kind of chaos in the city.
\end{abstract}


On the other hand, it also brings benefits such as the increase of local trade, the expansion of popular culture, and leisure to the revelers. Thus, discussing the Rio carnival is an essential topic to understand the right of access to the city. The carnival in the streets of Rio de Janeiro is an eminently popular carnival. It is a free party; the municipality prohibits the creation of placeholders or cabins on city streets. Therefore, in theory, anyone can join the crowd. With sponsored blocks and other ones kept by revelers themselves, the carnival changes the city. The street is no longer just a pathway - it is now occupied by people. The noise of vehicles is replaced by music, traditional in most cases. So, even bringing chaos along with the music and culture, the experience of the carnival, as a traditional Brazilian popular party, clearly becomes a public practice of the right to the city, since the gentrification process is momentarily neutralized and the government power intervention has to be limited - never to prohibit, but only to facilitate and enable a peaceful coexistence.

KEYWORDS: Right to the city. Rio de Janeiro. Street carnival.

Recebido: 23 de setembro de 2014

Aprovado: 9 de fevereiro de 2015 